Article

\title{
Conservation Farming and Changing Climate: More Beneficial than Conventional Methods for Degraded Ugandan Soils
}

\author{
Drake N. Mubiru ${ }^{1, *}$, Jalia Namakula ${ }^{1}$, James Lwasa ${ }^{1}$, Godfrey A. Otim ${ }^{1}$, Joselyn Kashagama ${ }^{1}$, \\ Milly Nakafeero ${ }^{1}$, William Nanyeenya ${ }^{1}$ and Mark S. Coyne ${ }^{2}$ \\ 1 National Agricultural Research Organization (NARO), P.O. Box 7065, Kampala, Uganda; \\ jalianamakula@kari.go.ug (J.N.); jlwasa@kari.go.ug (J.L.); ogodfrey@kari.go.ug (G.A.O.); \\ jkashagama@kari.go.ug (J.K.); mnakafeero@kari.go.ug (M.N.); nwilliam@kari.go.ug (W.N.) \\ 2 Department of Plant and Soil Sciences, University of Kentucky, 1100 S. Limestone St., Lexington, \\ KY 40546-0091, USA; mark.coyne@uky.edu \\ * Correspondence: dnmubiru@kari.go.ug; Tel.: +256-782-415-843
}

Received: 13 March 2017; Accepted: 14 June 2017; Published: 30 June 2017

\begin{abstract}
The extent of land affected by degradation in Uganda ranges from $20 \%$ in relatively flat and vegetation-covered areas to $90 \%$ in the eastern and southwestern highlands. Land degradation has adversely affected smallholder agro-ecosystems including direct damage and loss of critical ecosystem services such as agricultural land/soil and biodiversity. This study evaluated the extent of bare grounds in Nakasongola, one of the districts in the Cattle Corridor of Uganda and the yield responses of maize (Zea mays) and common bean (Phaseolus vulgaris L.) to different tillage methods in the district. Bare ground was determined by a supervised multi-band satellite image classification using the Maximum Likelihood Classifier (MLC). Field trials on maize and bean grain yield responses to tillage practices used a randomized complete block design with three replications, evaluating conventional farmer practice (CFP); permanent planting basins (PPB); and rip lines, with or without fertilizer in maize and bean rotations. Bare ground coverage in the Nakasongola District was $187 \mathrm{~km}^{2}$ $(11 \%)$ of the $1741 \mathrm{~km}^{2}$ of arable land due to extreme cases of soil compaction. All practices, whether conventional or the newly introduced conservation farming practices in combination with fertilizer increased bean and maize grain yields, albeit with minimal statistical significance in some cases. The newly introduced conservation farming tillage practices increased the bean grain yield relative to conventional practices by $41 \%$ in PPBs and $43 \%$ in rip lines. In maize, the newly introduced conservation farming tillage practices increased the grain yield by $78 \%$ on average, relative to conventional practices. Apparently, conservation farming tillage methods proved beneficial relative to conventional methods on degraded soils, with the short-term benefit of increasing land productivity leading to better harvests and food security.
\end{abstract}

Keywords: land degradation; land management; conservation farming

\section{Introduction}

Land degradation arising from inefficient and unsustainable land management is reducing crop productivity across sub-Saharan Africa (SSA). Land degradation reportedly affects $67 \%$ of SSA, and in some countries, more than $30 \%$ of the land area is severely or very severely degraded [1]. This is the case despite most households overwhelmingly relying on land resources [1]. The impacts of land degradation, which are becoming increasingly severe and are accelerating, include low crop productivity leading to food insecurity and disruption of ecosystem functions, which reduces ecosystem performance, resilience, and stability. The combined effects of the land degradation impacts are poor human livelihoods and wellbeing. 
The extent of land affected by degradation in Uganda ranges from $20 \%$ in relatively flat and vegetation-covered areas, to $90 \%$ in the eastern and southwestern highlands [2,3]. Earlier observations indicated that land/soil degradation and soil fertility are major impediments in all cropping systems in Uganda, especially where there has been agricultural intensification [4]. However, as elsewhere in SSA, much of the population depends on land for their livelihoods [5-7] and therefore suffers the repercussions of land degradation. Additionally, climate change is a major influence on the food security and livelihoods of households in Uganda, which mostly depend on rain-fed agriculture, and are increasingly at risk from perpetually low yields of major staples such as maize (Zea mays) [8-11] and common beans (Phaseolus vulgaris L.) [12]. Many households must deal with degraded, nutrient-starved soils, and the inability to access or purchase inputs such as improved seeds and fertilizer [13].

To its comparative advantage over the rest of SSA, Uganda has a diverse agricultural production system within 10 agricultural production zones (APZs) [14]. The zones are characterized by different farming systems determined by soil types, climate, topography, and socio-economic and cultural factors. Due to the different zonal characteristics, the APZs experience varying levels of land degradation and vulnerability to climate-related hazards, which include drought, floods, storms, pests, and disease [5].

Soil/land degradation stemming from deforestation, burning of grasslands and organic residues, and continuous cultivation with minimum soil fertility enhancement leads to soil erosion and organic matter and nutrient depletion $[13,15,16]$. Other unsustainable land-use practices, such as overgrazing, have produced compacted soil layers and often bare grounds in extreme cases [13]. Another underlying factor in the development of compacted soil layers is that hand-hoeing, which only disturbs the first 15 to $20 \mathrm{~cm}$-or sometimes as little as $5 \mathrm{~cm}$ - of the topsoil, when done consistently and regularly, can potentially produce restrictive layers below $0-20 \mathrm{~cm}$ of the topsoil. Under these soil conditions, nutrient- and water-use efficiency is reportedly very low $[17,18]$. These soil layers act as barriers to root and water movement and soil water-holding capacity (WHC), making land susceptible to the frequency and intensity of rainfall. Soil compaction in these layers affects agricultural land in several ways, including inhibiting root and water movement, limiting water infiltration and retention (hence facilitating runoff), and making plowing difficult. As a consequence, this directly affects agricultural productivity and contributes to the yield gap between potential output vis-à-vis farmer outputs. In that regard, land degradation and a total dependence on rain-fed agriculture has increased the vulnerability of farming systems and predisposed rural households to food insecurity and poverty [13]. Furthermore, it has led to significant adverse impacts on smallholder agro-ecosystems, including direct damage and loss of critical ecosystem services such as agricultural land/soil and biodiversity.

Due to climate change, the frequency and severity of climate-related hazards have increased, severely affecting agricultural production and in many cases leading to instability in agricultural production systems $[19,20]$. For example, poor rains severely affect pastures and livestock in most pastoral areas of the country, resulting in the migration of thousands of people and animals in search of water and food [5]. Jennings and Magrath [21] noted that excessive rains, both in intensity and duration, lead to water logging and negatively affect crops and pastures.

Past climatic scenarios make the outlook for the future unsettling; empirical evidence shows that seven droughts were experienced between 1991 and 2000. This caused severe water shortages, which seriously affected the animal industry [5]. Other impacts included low crop yields and increased food prices, culminating in food insecurity and negative effects on the economy. An increase in the intensity and frequency of heavy rains, floods, and landslides in the highland areas in the eastern, western, and southwestern parts of the country has been documented [22]. The recent severe drought in 2016 affected thousands of people, mainly in the Karamoja and Teso sub-regions and Isingiro District of southwestern Uganda. This was followed by the outbreak of the fall armyworm (Spodoptera frugiperda), affecting thousands of hectares of maize planted in the early 2017 season. The effects of climate change and variability in Uganda are compounded by existing developmental challenges of high population growth rates, high and increasing poverty levels, and declining GDP growth rates. Thus, climate 
change can undermine and even undo significant gains in social and economic developments in the country.

Unsustainable land-use practices lead to land degradation, and reduce the ecological and social resilience of landscapes. The overall impact of degradation has been the disruption of ecosystem services, particularly provisioning services, due to habitat fragmentation that reduces complexity and diversity, and soil erosion with consequent declining fertility and productivity. The situation is further aggravated by high population growth rates, which have led to extensive land fragmentation-a problem for sustainable land management [23]. Average landholdings in Uganda range from 0.4 to 3 ha for each typical household of seven persons [24]. High population areas are also often associated with poverty, thus requiring improved management systems to increase food security. Without a doubt, Uganda needs meaningful mitigation measures for the protection, recovery, and rehabilitation of the ecosystem services. The viability, functionality, and quality of ecosystem services are essential in enhancing and supporting community health and wellbeing, prosperity, and sustainability [25].

Ecosystem-based land management practices, such as conservation farming, bestow adaptive benefits that reduce the negative impacts of extreme weather events by buffering temperature extremes, harvesting and conserving rainwater, reducing soil loss within the agro-ecosystem, improving soil physicochemical and biological conditions, and regulating pest and disease cycles. Conservation farming practices can potentially address the soil and water management constraints faced by smallholder farmers [26]. The conservation farming package entails dry-season land preparation using minimum tillage systems, crop residue retention, seeding and input applications in permanent planting stations, and nitrogen-fixing crop rotations [27].

Permanent planting basins (PPBs) and rip lines are two major components of the recently introduced conservation farming package for renovating degraded landscapes that are being extensively promoted for smallholder farming [26,28-31]. PPBs and rip lines, as used in conservation farming, are crop management methods that enhance the capture and storage of rainwater, and allow sustainable precision management of limited nutrient resources. Both methods reduce the risk of crop failure due to erratic rainfall and extended droughts. The use of these methods in combination with improved seed and crop residues to create a mulch cover that reduces evaporation losses has consistently increased average yields by $50-200 \%$, depending on the amount of rainfall, soil type, and fertility [32]. PPBs are being targeted for households with limited or no access to oxen, while ripping is meant for smallholder farmers with oxen [26].

Maize and beans are major staple foods for much of the population, and are a major source of food security in Uganda. The annual per capita maize consumption is estimated to be $28 \mathrm{~kg}$, and bean consumption, $58 \mathrm{~kg}$ [33]. Both crops are cash crops for some smallholder farmers. Maize is also an important animal feed. At the household level, the importance of maize and beans is centered on their dietary roles of supplying proteins, carbohydrates, minerals, and vitamins to resource-constrained rural and urban households with rampant shortages of these dietary elements. Reportedly, the dietary intake for the most resource-constrained households in Uganda comprises $70 \%$ carbohydrates, and these are mainly from maize, supplying $451 \mathrm{kcal} /$ person/day and $11 \mathrm{~g}$ protein/person/day. Beans provide about $25 \%$ of the total calories and $45 \%$ of the protein intake in the diets of many Ugandans [34].

Unfortunately, due to the biophysical and socio-economic factors previously noted, the average maize and bean grain yields on smallholder farms, which on average are less than 1 ha, are less than $30 \%$ of their potentials [8-12]. The potential maize yield in Uganda is estimated to range from 3.8 to $8.0 \mathrm{tha}^{-1}$ [9], while that of beans is $2.0 \mathrm{tha}^{-1}$ [12]. Poor soil conditions (low soil fertility, compacted soils, and moisture stress) coupled with a low nutrient- and water-use efficiency are major contributing factors to this yield gap.

We postulate that employing ecosystem-based land management practices such as conservation farming will increase water- and nutrient-use efficiency, provide greater rooting depth, and improve WHC that would increase land productivity, leading to better grain harvests and food security. The 
long-term benefits would be an increased soil organic matter content, increased return on fertilizer use, and greater resilience of dry-land smallholder plots to erratic rainfall patterns from climate change.

This study: (i) assessed the extent of bare grounds in Nakasongola, one of the districts in the Cattle Corridor of Uganda; and (ii) evaluated yield responses of maize and beans to different tillage methods in the district.

\section{Materials and Methods}

\subsection{Site Description}

The Nakasongola District is in central Uganda, between $00^{\circ} 57^{\prime} 44.89^{\prime \prime}$ and $10^{\circ} 40^{\prime} 42.76^{\prime \prime}$ North latitude and between $310^{\circ} 58^{\prime} 03.77^{\prime \prime}$ and $320^{\circ} 48^{\prime} 00.29^{\prime \prime}$ East longitude. The district is in the Pastoral Rangelands agro-ecological zone (AEZ), which is one of the AEZs that comprise the Cattle Corridor of Uganda (Figure 1).

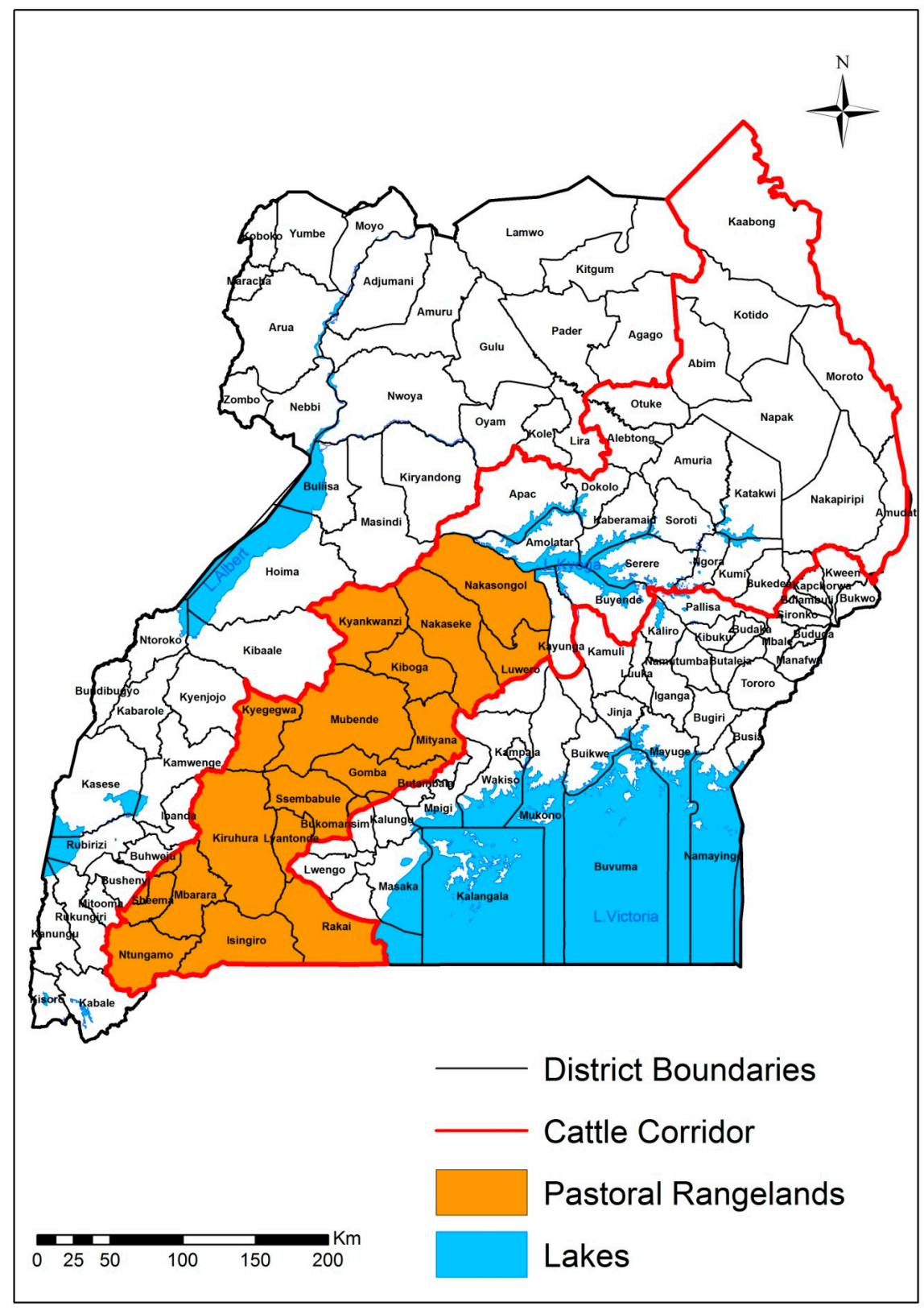

Figure 1. Uganda's Cattle Corridor (Source: Land Resources Database, NARL-Kawanda). 
Constituting the country's rangelands, the Cattle Corridor has a total area coverage of $84,000 \mathrm{~km}^{2}$, which is approximately one-third of the total $241,000 \mathrm{~km}^{2}$ of the land area in Uganda, and is home to a population of 6.6 million people. The corridor is host to a mixed production system comprising nomadic pastoralists, agro-pastoralists, and subsistence farmers. On average, it receives 500-1000 mm of rainfall annually, which is spatially variable, from about $400 \mathrm{~mm}$ in some parts of the northeastern corridor, to about $1200 \mathrm{~mm}$ in parts of the southwestern and central corridor. The rainfall pattern is bimodal in the southwestern and central parts of the corridor, and transitions into one rainy season of about $5 \frac{1}{2}$ months in the northern and northeastern areas [14]. Dry spells are frequent, and droughts of significant magnitudes occur, causing hardship to peoples' livelihoods and economy in the districts that comprise the corridor.

Specifically, the Pastoral Rangelands AEZ receives moderate rainfall, spatially varying from 915 to $1021 \mathrm{~mm} /$ year with a bimodal pattern [14]. The main rainy season is from March to May with a peak in April, and the secondary season is from September to December with a modest peak in November. Dry periods are from June to August and January to February. The daily average temperature ranges from 12.5 to $30^{\circ} \mathrm{C}$. Evaporation exceeds rainfall by a factor of about 6 during the dry months from June to August, while during the main rainy months (April and May), rainfall equals evaporation. Altitude in the zone spatially ranges from 129 to $1524 \mathrm{~m}$ ASL (above sea level), with the land characterized by rolling hills with some flat areas and moderate-to-poor soils. The farming system and socio-economic characteristics are characterized by smallholders with many communal grazing and agro-pastoral practices; low literacy levels; absentee landlords with a squatter population; and infrastructure and marketing systems that are poor to moderate $[13,14]$.

\subsection{Assessing the State of the Soil in the Nakasongola District}

\subsubsection{Quantification of Bare Ground Coverage}

Based on the assumption that bare grounds are one of the visible indicators of extreme land degradation, the approach was to physically survey and capture, using GPS, the spatial extent of some bare grounds, and use the data to locate the same features on a satellite image captured during a fairly dry month. These points were used to develop digital signatures for searching similar features in the rest of the image, and generating coverage statistics using Geographic Information System (GIS) tools.

\subsubsection{Data Sources/Analysis}

A supervised multi-band satellite image classification using the Maximum Likelihood Classifier (MLC) was used [35]. A high resolution $(<5 \mathrm{M})$ image from 2013, covering a greater part of the district, was used for the analysis. Bands 1, 4, and 7 of the Landsat Thematic Mapper image (p171r059_7t20011127_z36_nn10) were used.

\subsubsection{Soil Physicochemical Analysis}

Soil samples from depths of 0 to $20 \mathrm{~cm}$ were collected from geo-referenced sites in eight sub-counties comprising the Nakasongola District. The samples were dried in open air, ground to pass a $2 \mathrm{~mm}$ sieve, and analyzed according to Okalebo et al. [36] and Foster [37]. Texture analysis was performed by the hydrometer method [38]. Soil $\mathrm{pH}$ was measured with a soil/water ratio of 1:2.5. Extractable $\mathrm{P}, \mathrm{K}$, and $\mathrm{Ca}$ were measured in a single ammonium lactate/acetic acid extract buffered at pH 3.8 [36]. Total nitrogen $(\mathrm{N})$ was determined by a micro-Kjeldahl block digestion apparatus, and soil organic matter was determined by acid-dichromate digestion. Soil samples were also collected using a double-cylinder, hammer-driven core sampler to determine the bulk density according to methods by Blake and Hartge [39]. 


\subsubsection{Statistical Analysis}

The soils' physicochemical data was subjected to Pearson's correlation to establish relationships among the parameters, using Statistix V. 2.0. Furthermore, Principal Component Analysis (PCA) was used to determine similarities among soils from different farms and sub-counties as manifested in the status of their physicochemical properties.

\subsection{Sustainable Agricultural Production}

Sustainable agriculture has been defined as a means of production that seeks to sustain farmers, resources, and communities by promoting farming practices and methods that are profitable, environmentally sound, and good for communities [40-44]. Sustainability rests on the principle that the present generation must meet its own needs without compromising the ability of future generations to meet their own needs [44]. In this study, we assessed how conservation farming practices could contribute to sustainable agriculture production.

Trials were conducted on 16 randomly-selected farmer fields in the first and second seasons of 2015 in two sub-counties in the Nakasongola District. The first season (A) ran from March to May with a rainfall peak in April, while the second season (B) ran from October to December with a peak in November.

\subsubsection{Field Design}

The experiment design was a randomized complete block with three replications. The different tillage methods under assessment were: Conventional Farmer Practices (CFPs), PPBs, and rip lines, all with or without fertilizer. CFP entailed the preparation of a seedbed followed by at least two hand-hoe weeding passes, with crop residues incorporated into the soil.

Prior to the trial's establishment, in conservation farming treatments, the fields were slashed and sprayed with glyphosate $\left(500 \mathrm{mg} \mathrm{L}^{-1}\right)$ at a rate of $7.5 \mathrm{~L} \mathrm{ha}^{-1}$, two weeks after slashing. In the preceding cropping season, most fields had been used to grow maize, beans, or sweet potatoes (Ipomoea batatas). Due diligence was made to ensure that there was no continuous cropping of a particular crop in the same plot. The traditional crop rotations in this area are: sweet potato, bean or groundnut (Arachis hypogea), maize, then cassava (Manihot esculenta). Sweet potato is important as a first crop in the rotation because it helps to loosen, as well as increase, the soil volume, while cassava, which is tolerant to low soil nutrient levels, comes last in the rotation (Sarah Nakamya per. Comm., [45]). Due to multiple uses of crop residues, little material was laid down on the plots. In the conservation farming treatments, weeds were controlled by light weeding with a hand-hoe or by hand. A high-yielding and drought-tolerant hybrid maize variety (PH5052) and bean variety (NABE 15) were used in all treatments. The average plot size was $513 \mathrm{~m}^{2}$.

\subsubsection{Seeding Rates}

Conventional Farmer Practice: Planting holes for maize were designated by planting lines and digging with a hand-hoe at a spacing of $75 \mathrm{~cm}$ between rows and $60 \mathrm{~cm}$ within rows. Each hole was seeded with two seeds, giving a total of 44,444 plants/ha. In the case of beans, spacing was $50 \mathrm{~cm} \times 10 \mathrm{~cm}$ and each hole was seeded with one seed to give a total of 200,000 plants/ha.

Permanent Planting Basins: Basins were designated using planting lines and digging planting basins $35 \mathrm{~cm}$ (long) $\times 15 \mathrm{~cm}$ (wide) $\times 15 \mathrm{~cm}$ (deep), with a spacing of $75 \mathrm{~cm}$ between rows and $70 \mathrm{~cm}$ within rows from center-to-center of the PPB, before the onset of rains. Available crop residues were laid between rows to create a mulch cover. The basins were seeded with three maize seeds per basin (57,143 plants/ha) and six bean seeds per basin (114,286 plants/ha).

Rip lines: Rip lines were ripped before the onset of rains by an ox ripper set at a depth of $15 \mathrm{~cm}$. Available crop residues were laid between rows to create a mulch cover. Maize was seeded at a 
spacing of $75 \mathrm{~cm} \times 30 \mathrm{~cm}$ with one seed per hill (44,444 plants/ha). Beans were seeded at a spacing of $75 \mathrm{~cm} \times 10 \mathrm{~cm}$ with two seeds per hill (266,667 plants/ha).

In the maize and bean trials, micro-doses of basal fertilizer (DAP) at a rate of $92.5 \mathrm{~kg} \mathrm{ha}^{-1}$ were applied and covered with topsoil before planting the seeds. For maize, nitrogen as urea at a rate of $150 \mathrm{~kg} \mathrm{ha}^{-1}$ was evenly side-dressed when the maize was at knee height, approximately at vegetative stage 9 (V9).

\subsection{Statistical Analysis}

Data was examined by ANOVA to determine significant $(p \leq 0.05)$ treatment effects. Comparisons of means were made by LSD all-pair-wise comparisons. All analyses were done using Statistix V. 2.0.

\section{Results and Discussion}

\subsection{Assessment of the State of the Soil in the Nakasongola District}

\section{Quantification of Bare Ground Coverage}

Bare ground coverage in the Nakasongola District due to extreme cases of soil compaction was $187 \mathrm{~km}^{2}(11 \%)$ of the $1741 \mathrm{~km}^{2}$ of arable land (Figure 2 and Table 1). At present, Uganda has 7.2 million hectares of arable land under crop agriculture, which is less than $50 \%$ of the arable land estimated at 16.8 million hectares [6]. Pessimistic forecasts indicate that the available arable land for agriculture will run out in most parts of the country by around 2022. With such grim statistics, the country cannot afford to lose any arable land. It is therefore imperative that Uganda embraces sustainable land management to reverse this trend of land degradation.

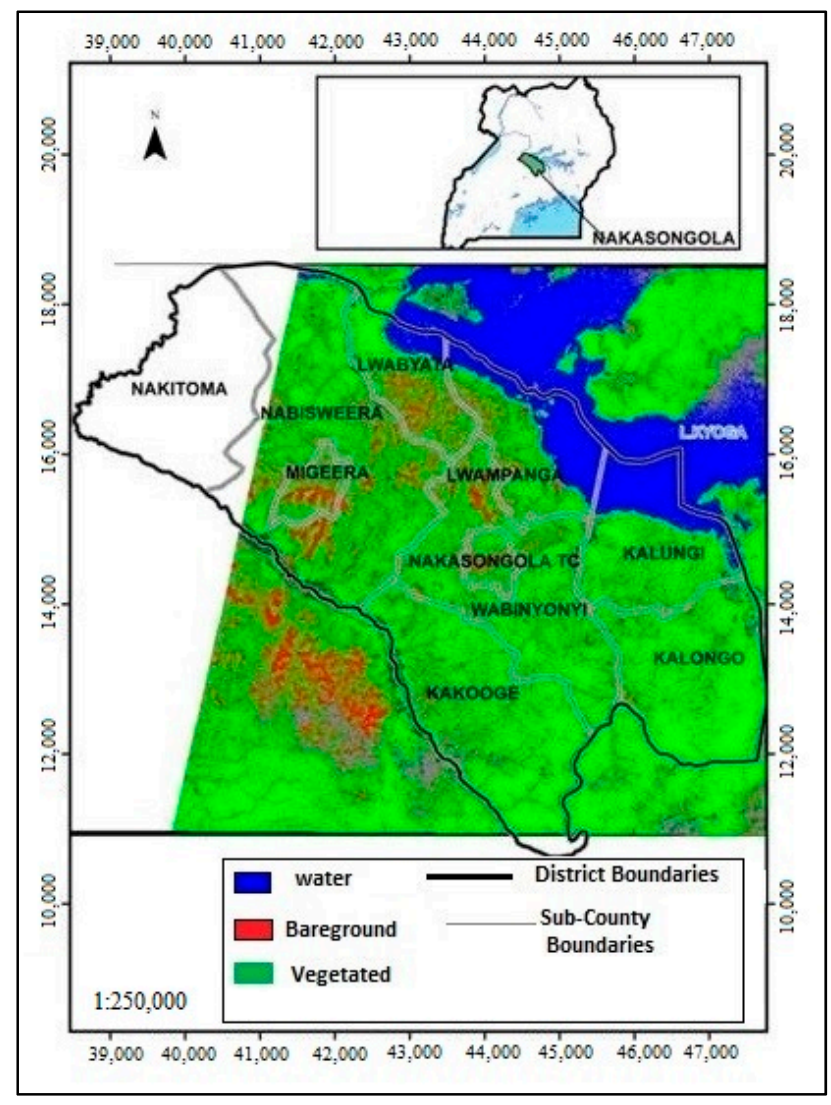

Figure 2. Spatial distribution of bare-grounds in the Nakasongola District and surrounding areas. 
Table 1. Spatial distribution of different land cover classes in the Nakasongola District.

\begin{tabular}{cccc}
\hline & Class & Area $\mathbf{( k m}^{\mathbf{2}} \mathbf{)}$ & \% Cover \\
\hline 1 & Open water & 233 & 7.9 \\
2 & Vegetated & 1527 & 51.7 \\
3 & Bare ground & 187 & 6.3 \\
4 & Seasonal wetland & 915 & 31.0 \\
5 & Cloud cover & 48 & 1.6 \\
6 & Permanent wetland & 46 & 1.6 \\
Total & & 2956 & 100 \\
\hline
\end{tabular}

Pearson's correlation (Table 2) of soil physicochemical data from all sub-counties revealed that the bulk density, which was used as an indicator of soil compaction, was significantly correlated only with clay $(r=-0.54, p<0.0003)$ and sand $(r=0.48, p<0.002)$. Therefore, clay and sand were the most important determinant parameters for bulk density or soil compaction. Observations from our study are well corroborated by several workers [46-50], who observed, from different areas and soil types, that the higher the amount of sand in the soil, the greater the bulk density, while the higher the amount of clay, the lower the bulk density.

Table 2. Pearson's correlation of soil physicochemical data from all sub-counties in the Nakasongola District.

\begin{tabular}{ccccccccccc}
\hline & $\mathbf{p H}$ & $\mathbf{O M}$ & $\mathbf{N}$ & $\mathbf{P}$ & $\mathbf{K}$ & $\mathbf{C a}$ & $\mathbf{M g}$ & Sand & Silt & Clay \\
\hline $\mathrm{OM}$ & $0.27^{*}$ & & & & & & & & & \\
$\mathrm{~N}$ & $0.28^{*}$ & $0.97^{* * *}$ & & & & & & & \\
$\mathrm{P}$ & $0.57^{* * *}$ & 0.19 & 0.20 & & & & & & \\
$\mathrm{~K}$ & $0.42^{* * *}$ & -0.05 & -0.03 & $0.30^{*}$ & & & & & \\
$\mathrm{Ca}$ & $0.82^{* * *}$ & $0.33^{* *}$ & $0.31^{* *}$ & $0.40^{* * *}$ & 0.26 & & & & \\
$\mathrm{Mg}$ & $0.79^{* * *}$ & $0.31^{* *}$ & $0.30^{*}$ & $0.36^{* *}$ & $0.38^{* *}$ & $0.97^{* * *}$ & & & \\
Sand & -0.14 & $-0.48^{* * *}$ & $-0.49^{* * *}$ & -0.07 & -0.13 & -0.26 & $-0.29^{*}$ & & & \\
Silt & $0.50^{* * *}$ & $0.53^{* * *}$ & $0.52^{* * *}$ & 0.14 & 0.03 & $0.60^{* * *}$ & $0.55^{* * *}$ & $-0.45^{* * *}$ & & \\
Clay & $-0.07^{* *}$ & $0.30^{*}$ & $0.32^{* *}$ & 0.01 & 0.13 & 0.03 & 0.08 & $-0.92^{* * *}$ & 0.05 & \\
BD $^{+}$ & 0.23 & -0.18 & -0.16 & 0.19 & 0.03 & 0.16 & 0.13 & $0.48^{* * *}$ & 0.01 & $-0.54^{* * *}$ \\
\hline
\end{tabular}

${ }^{+} \mathrm{BD}=$ Bulk Density; ${ }^{*} \mathrm{OM}=$ Organic Matter; ${ }^{*}$ significant at 0.1 level; ${ }^{* *}$ significant at the 0.05 level; ${ }^{* * *}$ significant at the 0.01 level.

PCA was used to determine if there were similarity clusters of soils from different farms and sub-counties with respect to soil properties. All soils from the different farms and sub-counties formed one cluster, indicating that there were no exceptional differences in the soil properties among the sub-counties. Means of all soil properties (Table 3) in the topsoils and subsoils were below normal for the soils of Uganda [36]. For example, the critical value of soil $\mathrm{pH}$ in Ugandan soils is 5.6, while that of organic carbon is 3.0\% [51,52]; this is an indication that all soils in this study were, to some extent, chemically and physically degraded. On analyzing the properties of the topsoil and subsoil, the average $\mathrm{pH}$ of the subsoil was slightly higher than that of the topsoil, which was unusual. However, the concentration of calcium in the subsoil was also higher than in the topsoil, which might explain this phenomenon.

Although there was no distinct differentiation for soils from the different farms and sub-counties, separately, soils from the Kalungi sub-county had the highest average bulk density (Table 4), which was significantly different $(p \leq 0.05)$ from the other sub-counties, except Kalongo and Lwampanga. Soils from the Wabinyonyi and Kakoge sub-counties had the lowest $(p \leq 0.05)$ average bulk densities compared to the other sub-counties. Correspondingly, the Wabinyonyi and Kakoge sub-counties also had a higher $(p \leq 0.05)$ percentage of clay and a significantly lower percentage of sand than all the other sub-counties, with a few exceptions. 
Table 3. Cluster means of soil properties for soil samples from sub-counties of the Nakasongola District.

\begin{tabular}{|c|c|c|c|c|c|c|c|c|c|c|c|}
\hline \multirow{2}{*}{$\begin{array}{c}\text { Soil } \\
\text { Layer }\end{array}$} & $\mathrm{BD}^{+}$ & $\mathrm{pH}$ & $\mathrm{OM}^{*}$ & $\mathbf{N}$ & $\mathbf{P}$ & K & $\mathrm{Ca}$ & $\mathrm{Mg}$ & Sand & Clay & Silt \\
\hline & (g/cc) & & \multicolumn{2}{|c|}{$(\%)$} & \multicolumn{4}{|c|}{ (ppm) } & \multicolumn{3}{|c|}{$(\%)$} \\
\hline Topsoil $^{¥}$ & 1.4 & 4.4 & 2.2 & 0.2 & 6.3 & 98.8 & 459 & 283 & 51 & 41 & 8 \\
\hline Subsoil ${ }^{¥}$ & - & 4.6 & 2.1 & 0.1 & 3.1 & 45.4 & 571 & 217 & 50 & 42 & 8 \\
\hline $\begin{array}{c}\text { Critical } \\
\text { levels }\end{array}$ & & 5.6 & 3.0 & 0.2 & 35.5 & 72.5 & 1640 & 87 & & & \\
\hline
\end{tabular}

Table 4. Soil properties well-correlated with bulk density from the different sub-counties.

\begin{tabular}{cccc}
\hline \multirow{2}{*}{ Sub-County } & \multicolumn{3}{c}{ Soil Property $^{\mathbf{1}}$} \\
\cline { 2 - 4 } & Bulk Density (g/cc) & Clay (\%) & Sand (\%) \\
\hline Kalungi & $1.58 \mathbf{a}$ & $42 \mathbf{b} \mathbf{c}$ & $51 \mathbf{a b}$ \\
Kalongo & $1.57 \mathbf{a b}$ & $38 \mathbf{c}$ & $57 \mathbf{a}$ \\
Lwampanga & $1.56 \mathbf{a b}$ & $40 \mathrm{c}$ & $50 \mathbf{a b}$ \\
Rwabyata & $1.49 \mathbf{b c}$ & $38 \mathbf{c}$ & $53 \mathbf{a}$ \\
Nakitoma & $1.47 \mathbf{c}$ & $37 \mathbf{c}$ & $56 \mathbf{a}$ \\
Nabisweera & $1.44 \mathrm{c}$ & $37 \mathrm{c}$ & $54 \mathbf{a}$ \\
Wabinyonyi & $1.34 \mathbf{d}$ & $47 \mathbf{a b}$ & $44 \mathbf{b}$ \\
Kakooge & $1.33 \mathbf{d}$ & $50 \mathbf{a}$ & $44 \mathbf{b}$ \\
SE & 0.04 & 3 & 4 \\
\hline
\end{tabular}

${ }^{1}$ Different letters within each column indicate significant differences between treatments at the $p \leq 0.05$ level, using the LSD method.

\subsection{Sustainable Agricultural Production}

\subsubsection{Bean Grain Yield Response to Tillage Practices and Fertilizer}

There were no significant seasonal differences in the bean grain yield (Table 5). There were also no significant season $\times$ tillage interactions, indicating that treatment effects on the grain yield were independent of seasonal characteristics. Since the season $\times$ tillage interactions were not significant, the yield means were averaged across the seasons (Table 5). All tillage practices, whether conventional or the newly introduced conservation farming practices in combination with a fertilizer increased bean grain yield. However, the increases were only significantly different between rip lines with and without fertilizer. On average, fertilizer use in combination with the tillage practices increased the bean grain yield from $436 \mathrm{~kg} \mathrm{ha}^{-1}$ to $743 \mathrm{~kg} \mathrm{ha}^{-1}$, a $70 \%$ increase. Separately, the highest average percentage yield increase $(102 \%)$ was between rip lines with and without fertilizer; this was followed by conventional practices without and with fertilizer (56\%), and lastly between PPBs without and with fertilizer (53\%). The average bean grain yield from conventional practices was $460 \mathrm{~kg} \mathrm{ha}^{-1}$; from PPBs, $648 \mathrm{~kg} \mathrm{ha}^{-1}$; and from rip lines, $661 \mathrm{~kg} \mathrm{ha}^{-1}$. Apparently, the newly introduced conservation farming tillage practices increased the bean grain yield relative to conventional practices by $41 \%$ in PPBs, and $43 \%$ in rip lines.

Table 5. Average bean and maize grain yields as a response to different tillage practices ${ }^{\dagger}$.

\begin{tabular}{ccccc}
\hline \multirow{2}{*}{ Tillage Practice } & \multicolumn{2}{c}{ Bean Yield } & \multicolumn{2}{c}{ Maize Yield } \\
\cline { 2 - 5 } & $\mathbf{( k g ~ h a} \mathbf{~}^{\mathbf{1}} \mathbf{)}$ & SE & $\mathbf{( k g ~ h a}^{\mathbf{- 1}} \mathbf{)}$ & SE \\
\hline Conventional & $359 \mathbf{c}$ & \pm 138 & $1536 \mathbf{b}$ & \pm 879 \\
Conventional + fertilizer & $560 \mathbf{a b c}$ & \pm 138 & $2481 \mathbf{a b}$ & \pm 879 \\
PPB & $512 \mathbf{a b c}$ & \pm 138 & $3328 \mathbf{a b}$ & \pm 918 \\
PPB + fertilizer & $784 \mathbf{a b}$ & \pm 138 & $4963 \mathbf{a}$ & \pm 918 \\
Rip line & $438 \mathbf{b c}$ & \pm 148 & $2086 \mathbf{b}$ & \pm 963 \\
Rip line + fertilizer & $884 \mathbf{a}$ & \pm 148 & $3921 \mathbf{a b}$ & \pm 963 \\
\hline
\end{tabular}

\footnotetext{
+ Yield means for a particular crop followed by the same letter are not significantly different according to LSD at $p=0.05$.
} 


\subsubsection{Potential versus Actual Bean Grain Yield}

The potential bean grain yield in Uganda is about $2.0 \mathrm{tha}^{-1}$ [12]. In our study, the response of bean grain yields to fertilizer and the newly introduced conservation farming tillage practices was below the yield potential, notwithstanding the remarkable increase. Other workers [53-56] have observed that yields from on-farm trials were enhanced by using improved seeds and fertilizers, but yields still remained below the genetic potential. This has been attributed to management factors that contributed to poor early-season vigor, in-season plant loss, and environmental stresses.

The tillage effects increased the bean grain yield in the newly introduced conservation farming practices relative to conventional practices. However, the yield differences between rip lines and PPBs could partly be attributed to differences in plant population; that is, 266,667 plants/ha in rip line tillage vis-à-vis 114,286 plants ha ${ }^{-1}$ in PPBs. In an earlier study (not published) conducted to determine the optimum seeding rates in PBBs, it was established that six bean seeds per basin, as were used in the current study, was optimal. It is plausible that increasing the seeding rate in PPBs creates competition among the plants, thus affecting productivity.

Ghaffarzadeh et al. [57] observed that the potential for stress could be increased when crops compete among themselves. Ghaffarzadeh et al. [58] further intimated that competition for resources might develop because of root growth patterns and/or different resource demands, although they acknowledged that there is limited information available about light, water, and nutrient competition in regard to plant position. Some studies suggest that spatial and temporal arrangement of crops may influence competition for water and light $[59,60]$. Under water-limiting conditions, production advantages could diminish [61-63].

\subsubsection{Maize Grain Yield Response to Tillage Practices and Fertilizer}

Unlike for beans, there were significant seasonal differences in the maize grain yield (Table 5). In the first season (2015A), the maize grain yield was $2113 \mathrm{~kg} \mathrm{ha}^{-1}(106 \%)$ greater than in the second season (2015B). It is plausible that the yield difference was a result of water stress experienced in the 2015B season. This effect was more pronounced in maize than in beans because beans are short-term compared to maize, and it is likely that by the time drought manifested, the bean crop was already in advanced stages of development.

Although there were significant seasonal yield differences, the season $\times$ tillage interactions were not significant. As was the case with beans, this indicated that the tillage effects on the maize grain yield were independent of the seasonal characteristics. Correspondingly, the yield means were averaged across seasons (Table 5). As would be expected, there were yield responses to fertilizer applications in all tillage practices, however, the differences between particular tillage practices without and with fertilizer were minimally significant. Suffice to note also that the newly introduced conservation farming practices, on average, increased the grain yield more than the conventional practice, by $78 \%$. In their study spanning three seasons, Mazvimavi et al. [64] realized that maize in conservation farming tillage practices out-yielded that in conventional tillage practices by $59 \%$.

When each season was critically examined, this demonstrated the performance differences between the two conservation farming tillage practices. In season 2015A, which was deemed to have normal rainfall, rip line tillage had a higher maize grain yield compared to the PPBs. Conversely, in 2015B, which is believed to have had below-average rainfall, the PPBs had a higher maize grain yield compared to rip lines. Although it cannot be conclusively concluded from our study results, it is plausible that in years with below-average rainfall, the PPBs are better at harvesting and conserving rainwater than rip lines, and are thus the superior performer. In their study on conservation tillage for soil water management, Mupangwa et al. [26] concluded that planting basin tillage is better at controlling water losses than ripper, double, and single conventional ploughing techniques. 


\subsubsection{Potential versus Actual Maize Grain Yield}

The potential maize yield in Uganda is estimated to range from 3.8 to $8.0 \mathrm{tha}^{-1}$ [8-11], with the open pollinated varieties (OPV) being on the lower end compared to hybrid varieties. However, according to the Food and Agriculture Organization Statistical Database (FAOSTAT), the actual maize productivity is stagnant, at a low level of between 1.5 and $2.5 \mathrm{t} \mathrm{ha}^{-1}$ [11]. The yield gap is attributed to the limited use of inputs such as improved seed and fertilizer, now coupled with soil moisture stress due to climate variability. In the current study, the newly introduced conservation farming practices apparently brought the maize grain yield within the potential yield range, although there was still room for improvement.

\section{Conclusions}

This study showed that $11 \%$ of the arable land in the Nakasongola District is bare ground, an extreme case of soil compaction and land degradation. Because this is not an isolated case, it is imperative that the country embraces sustainable land management and agricultural production to meet the food needs of its people and to spur economic development, while at the same time conserving the environment.

The newly introduced conservation farming tillage practices increased the bean grain yield relative to conventional practices by $41 \%$ in PPBs and $43 \%$ in rip lines. For maize, the newly introduced conservation farming tillage practices on average increased the grain yield by $78 \%$, relative to the conventional practices. Conservation farming tillage methods, that is, PPBs and rip lines, proved to be more beneficial than conventional methods for degraded soils, with a short-term benefit of increasing land productivity, leading to better harvests and food security. The long-term benefits are expected to be an increased soil organic matter content, an increased return on fertilizer use, and a greater resilience of dryland smallholder plots to erratic rainfall patterns, occasioned by climate change. Conservation farming practices, as empirically tested in this study, facilitated the rehabilitation and recovery of degraded farmer fields, as evidenced by increased grain yields, thus fitting well within the league of sustainable agricultural production practices.

Long-term studies are needed to establish the effects of variable rainfall on the performance of planting basins vis-à-vis rip lines. Furthermore, considering the variable costs of inputs and the variability of outputs among the different tillage practices, there is a need to conduct a cost-benefit analysis to determine the cost effectiveness of each tillage practice.

Acknowledgments: The authors are grateful to the participating farmers and local government of the Nakasongola District. The research was supported by the National Agricultural Research Organization, the National Agricultural Research Laboratories-Kawanda, the International Maize and Wheat Improvement Centre (CIMMYT), and the Australian Centre for International Agricultural Research (ACIAR) through the Sustainable Intensification of Maize-Legume cropping systems for Food Security in Eastern and Southern Africa (SIMLESA) program. M.S. Coyne was supported by the USDA National Institute of Food and Agriculture Hatch project KY007090, with additional support from a Natural Resources Conservation Service Conservation Innovation Grant, and a USDA-ARS specific cooperative agreement. Funds to publish in open access were sourced from the Uganda Sustainable Land Management (SLM) project, financed by a grant from the Global Environment Facility (GEF).

Author Contributions: Drake N. Mubiru was the principal investigator and lead person in the experimentation process and preparation of the manuscript. Jalia Namakula, Godfrey Otim, Joselyn Kashagama, and Milly Nakafeero established and managed the trials, and collected the yield data. James Lwasa led the team in assessing the state of the soils in Nakasongola District using, Global Positioning System (GPS) and Geographic Information System (GIS) tools. William Nanyeenya collated all the socio-economic and biophysical information of Nakasongola District. Mark S. Coyne made significant intellectual contributions during the designing of the trials and for improving the technical content of the manuscript.

Conflicts of Interest: The authors declare no conflict of interest. 


\section{References}

1. FAO. World Soils Report. No. 90. 2000. Available online: www.fao.org/soils-portal/resources/world-soilresources-reports/en (accessed on 13 December 2016).

2. Magunda, M.K.; Tenwya, M.M. Soil and water conservation. In Agriculture in Uganda; Mukiibi, J.K., Ed.; Uganda National Agricultural Research Organization (NARO): Entebbe, Uganda, 2001; Volume I, pp. 145-168.

3. Nakileza, B.; Nsubuga, E.N.B. Rethinking Natural Resource Degradation in Semiarid Sub-Saharan Africa: A Review of Soil and Water Conservation Research and Practice in Uganda, with Particular Emphasis on the Semiarid Areas; Overseas Development Institute: Kampala, Uganda, 1999.

4. $\quad$ Nkonya, E.; Pender, J.; Jagger, P.; Sserunkuma, D.; Kaizzi, C.K.; Ssali, H. Strategies for Sustainable Land Management and Poverty Reduction in Uganda; Research Report 133; IFPRI: Washington, DC, USA, 2004.

5. Government of Uganda (GOU). Climate Change: Uganda National Adaptation Programmes of Action; Environmental Alert, GEF, UNEP, Ministry of Water and Environment: Kampala, Uganda, 2007.

6. National Environment Management Authority (NEMA). State of the Environment Report for Uganda 2006/2007; NEMA: Kampala, Uganda, 2007.

7. Uganda Bureau of Statistics (UBOS). Statistical Abstract. 2015. Available online: http://www.ubos.org (accessed on 11 February 2016).

8. Otunge, D.; Muchiri, N.; Wachoro, G.; Anguzu, R.; Wamboga-Mugirya, P. Enhancing Maize Productivity in Uganda Through the WEMA Project; A Policy Brief; National Agricultural Research Organisation of Uganda (NARO)/African Agricultural Technology Foundation (AATF): Entebbe, Uganda, 2010.

9. Semaana, H.R. Crop Production Handbook for Good Quality Cereals, Pulses and Tuber Crops; Ministry of Agriculture Animal Industry and Fisheries/Sasakawa Africa Association (SAA): Entebbe, Uganda, 2010.

10. Regional Agricultural Expansion Support (RATES). Maize Market Assessment and Baseline Study for Uganda; Regional Agricultural Expansion Support Program: Nairobi, Kenya, 2003.

11. Okoboi, G.; Muwanga, J.; Mwebaze, T. Use of improved inputs and its effects on maize yield and profit in Uganda. Afr. J. Food Agric. Nutr. Dev. 2012, 12, 6932-6944.

12. Sebuwufu, G.; Mazur, R.; Westgate, M.; Ugen, M. Improving the Yield and Quality of Common Beans in Uganda. Available online: www.soc.iastate.edu/staff/.../CRSP (accessed on 9 September 2014).

13. World Bank. Uganda Sustainable Land Management: Public Expenditure Review; Report No. 45781-UG AFTAR; Sustainable Development Department Country Department 1, Uganda Africa Region: Kampala, Uganda, 2008.

14. Government of Uganda (GOU). Increasing Incomes through Exports: A Plan for Zonal Agricultural Production, Agro-Processing and Marketing for Uganda; MAAIF: Entebbe, Uganda, 2004.

15. Magunda, M.; Majaliwa, M. Soil Erosion in Uganda: A Review; Nile Basin Initiative Issue Paper; NBI: Kampala, Uganda, 2006.

16. Zake, J.; Magunda, M.; Nkwiine, C. Integrated soil management for sustainable agriculture and food security: The Uganda case. Presented at the FAO Workshop on Integrated Soil Management for Sustainable Agriculture and Food Security in Southern and Eastern Africa, Harare, Zimbabwe, 8-12 December 1997.

17. Ewel, J.J. Nutrient Use Efficiency and the Management of Degraded Lands. In Ecology Today: An Anthology of Contemporary Ecological Research; Gopal, B., Pathak, P.S., Saxena, K.G., Eds.; International Scientific Publications: New Delhi, India, 1988; pp. 199-215.

18. Fatondji, D.; Martius, C.; Bielders, C.L.; Vlek, P.L.G.; Bationo, A.; Gerard, B. Effect of planting technique and amendment type on pearl millet yield, nutrient uptake, and water use on degraded land in Niger. Nutr. Cycl. Agroecosyst. 2006, 76, 203. [CrossRef]

19. Mubiru, D.N.; Komutunga, E.; Agona, A.; Apok, A.; Ngara, T. Characterising agrometeorological climate risks and uncertainties: Crop production in Uganda. S. Afr. J. Sci. 2012, 108. [CrossRef]

20. Ogallo, L.A.; Boulahya, M.S.; Keane, T. Applications of seasonal to interannual climate prediction in agricultural planning and operations. Int. J. Agric. For. Met. 2002, 103, 159-166. [CrossRef]

21. Jennings, S.; Magrath, J. What Happened to the Seasons? 2009. Available online: http:/ /www.oxfam.org. uk/resources/policy/climate_change/ (accessed on 11 August 2014).

22. National Environment Management Authority (NEMA). National State of the Environment Report for Uganda 2014; NEMA: Kampala, Uganda, 2016. 
23. United Nations Development Programme (UNDP). Uganda Strategic Investment Framework for Sustainable Land Management; UNDP: Kampala, Uganda, 2014.

24. Okwi, P.O.; Hoogeveen, J.G.; Emwanu, T.; Linderhof, V.; Begumana, J. Welfare and environment in rural Uganda: Results from a small-area estimation approach. Afr. Stat. J. 2016, 3, 135-188. [CrossRef]

25. Serrao-Neumann, S.; Turetta, A.P.; Prado, R.; Choy, D.L. Improving the management of climate change impacts to support resilient regional landscapes. In Proceedings of the Conference of the Ecosystem Services Partnership Local Action for the Common Good, San Jose, Costa Rica, 7-12 September 2014.

26. Mupangwa, W.; Twomlow, S.; Walker, S. Conservation Tillage for Soil Water Management in the Semiarid Southern Zimbabwe. Available online: http://www.cgspace.cgiar.org/bitstream/handle/ (accessed on 10 December 2014).

27. Haggblade, S.; Tembo, G. Early Evidence on Conservation Farming in Zambia. Presented at the International Workshop on Reconciling Rural Poverty and Resource Conservation: Identify Relationships and Remedies, Ithaca, NY, USA, 2-3 May 2003.

28. Hove, L.; Twomlow, S. Is conservation agriculture an option for vulnerable households in Southern Africa? Presented at the Conservation Agriculture for Sustainable Land Management to Improve the Livelihood of People in Dry Areas Workshop, Damascus, Syria, 7-9 May 2007.

29. Twomlow, S.; Urolov, J.; Oldrieve, J.C.; Jenrich, B. Lessons from the Field: Zimbabwe's Conservation Agriculture Task Force. J. SAT Agric. Res. 2008, 6, 1-11.

30. Mazvimavi, K.; Twomlow, S. Socioeconomic and institutional factors influencing adoption of conservation farming by vulnerable households in Zimbabwe. Agric. Syst. 2009, 101, 20-29. [CrossRef]

31. Pedzisa, I.; Minde, I.; Twomlow, S. An evaluation of the use of participatory processes in wide-scale dissemination of research in micro dosing and conservation agriculture in Zimbabwe. Res. Eval. 2010, 19, 145-155. [CrossRef]

32. Twomlow, S. Integrated Soil Fertility Management Case Study; SLM Technology, Precision Conservation Agriculture: Bulawayo, Zimbabwe, 2012.

33. Soniia, D.; Sperling, L. Improving technology delivery mechanisms: Lessons from bean seed systems research in eastern and central Africa. Agric. Hum. Values 1999, 16, 381-388.

34. National Agricultural Research Organization (NARO). Annual Report; NARO: Entebbe, Uganda, 2000.

35. Lillesand, T.M.; Kiefer, R.W. Remote Sensing and Image Interpretation; John Wiley \& Sons: New York, NY, USA, 1987; p. 669.

36. Okalebo, J.R.; Gathau, K.W.; Woomer, P.L. Laboratory Methods of Soil and Plant Analysis: A Working Manual; TSBF-CIAT and SACRED Africa: Nairobi, Kenya, 2002.

37. Foster, H.L. Rapid routine soil and plant analysis without automatic equipment: I. Routine soil analysis. E.Afr. Agric. For. J. 1971, 37, 160-170.

38. Gee, G.W.; Bauder, J.W. Particle-size analysis. In Methods of Soil Analysis, Part 1; SSSA Book Series 5; Klute, A., Ed.; Soil Science Society of America, American Society of Agronomy: Madison, WI, USA, 1986; pp. 383-411.

39. Blake, G.R.; Hartge, K.H. Bulk density. In Methods of Soil Analysis, Part 1; SSSA Book Series 5; Klute, A., Ed.; Soil Science Society of America, American Society of Agronomy: Madison, WI, USA, 1986; pp. 363-375.

40. National Sustainable Agriculture Coalition. Available online: http://sustainableagriculture.net/about-us / what-is-sustainable-ag/ (accessed on 31 May 2017).

41. Union of Concerned Scientists. Science for a Healthy Planet and Safer World. Available online: http:/ / www.ucsusa.org/food-agriculture/advance-sustainable-agriculture/what-is-sustainableagriculture\#.WS6WkpKGPIU (accessed on 31 May 2017).

42. UWestern SARE. Sustainable Agricultural Research and Education. Available online: http://www. westernsare.org/About-Us/What-is-Sustainable-Agriculture (accessed on 31 May 2017).

43. Grace Communications Foundation. Available online: http://www.sustaianble.org/246/sustainableagriculture-the-basics (accessed on 31 May 2017).

44. UCDAVIS Agricultural Sustainability Institute. Available online: http://asi.ucdavis.edu/programs/sarep/ about/what-is-sustainable-agriculture (accessed on 31 May 2017).

45. Musiitwa, F.; Komutunga, E. Agricultural systems. In Agriculture in Uganda; Mukiibi, J.K., Ed.; Uganda National Agricultural Research Organization (NARO): Entebbe, Uganda, 2001; Volume I, pp. 220-230.

46. Nelson, L.B.; Muckenhirn, R.J. Field percolation rates of four Wisconsin soils having different drainage characteristics. J. Am. Soc. Agron. 1941, 33, 1028-1036. [CrossRef] 
47. Fritton, D.D.; Olson, G.W. Bulk density of a fragipan soil in natural and disturbed profiles. Soil Sci. Soc. Am. Proc. 1972, 36, 686-689. [CrossRef]

48. Dawud, A.Y.; Gray, F. Establishment of the lower boundary of the sola of weakly developed soils that occur in Oklahoma. Soil Sci. Soc. Am. J. 1979, 43, 1201-1207. [CrossRef]

49. Larson, W.E.; Gupta, S.C.; Useche, R.A. Compression of agricultural soils from eight soil orders. Soil Sci. Soc. Am. J. 1980, 44, 450-457. [CrossRef]

50. Yule, D.F.; Ritchie, J.T. Soil shrinkage relationships of Texas Vertisols: I. Small cores. Soil Sci. Soc. Am. J. 1980, 44, 1285-1291. [CrossRef]

51. Ssali, H. Soil fertility. In Agriculture in Uganda; Mukiibi, J.K., Ed.; Uganda National Agricultural Research Organization (NARO): Entebbe, Uganda, 2001; Volume I, pp. 104-135.

52. Hazelton, P.; Murphy, B. Interpreting Soil Test Reults: What do the Numbers Mean? CSIRO: Collingwood, Australia, 2010.

53. Namugwanya, M.; Tenywa, J.S.; Etabbong, E.; Mubiru, D.N.; Basamba, T.A. Development of common bean (Phaseolous Vulgaris L.) production under low soil phosphorus and drought in sub Saharan Africa: A review. J. Sustain. Dev. 2014, 7, 128-139.

54. Goettsch, L.H.; Lenssen, A.W.; Yost, R.S.; Luvaga, E.S.; Semalulu, O.; Tenywa, M.; Mazur, R.E. Improved production systems for common bean on Phaeozem soil in south-central Uganda. Afr. J. Agric. Sci. 2016, 11, 4797-4809.

55. Kalyebara, R. The Impact of Improved Bush Bean Varieties in Uganda; Network on Bean Research in Africa, Occasional Publication Series 43; Chartered Institute of Architectural Technologists (CIAT): Kampala, Uganda, 2008.

56. Sibiko, K.W.; Ayuya, O.I.; Gido, E.O.; Mwangi, J.K. An analysis of economic efficiency in bean production: Evidence from eastern Uganda. J. Econ. Sustain. Dev. 2013, 4. Available online: www.iiste.org (accessed on 2 May 2017).

57. Ghaffarzadeh, M.; Garcia, F.; Cruse, R.M. Grain yield response of corn, soybean, and oat grown in strip intercropping system. Am. J. Altern. Agric. 1994, 9, 171-177. [CrossRef]

58. Ghaffarzadeh, M.; Garcia, F.; Cruse, R.M. Tillage effect on soil water content and corn yield in a strip intercropping system. Agron. J. 1997, 89, 893-899. [CrossRef]

59. Shaw, R.H.; Felch, R.E.; Duncan, E.R. Soil Moisture Available for Crop Growth; Special Report; Iowa State University: Ames, IA, USA, 1972.

60. Hulugalle, N.R.; Willatt, S.T. Seasonal variation in the water uptake and leaf water potential of intercropped and monocropped chillies. Exp. Agric. 1987, 23, 273-282. [CrossRef]

61. Francis, C.A.; Jones, A.; Crookston, K.; Wittler, K.; Goodman, S. Strip cropping corn and grain legumes: A review. Am. J. Altern. Agric. 1986, 1, 59-164.

62. Hulugalle, N.R.; Lal, R. Soil water balance in intercropped maize and cowpea in a tropical hydromorphic soil in western Nigeria. Agron. J. 1986, 77, 86-90. [CrossRef]

63. Fortin, M.C.; Culley, J.; Edwards, M. Soil water, plant growth, and yield of strip-intercropped corn. J. Prod. Agric. 1994, 7, 63-69. [CrossRef]

64. Mazvimavi, K.; Ndlovu, P.V.; Nyathi, P.; Minde, I.J. Conservation agriculture practices and adoption by smallholder farmers in Zimbabwe. Presented at the 3rd African Association of Agricultural Economists (AAAE) and 48th Agricultural Economists Association of South Africa (AEASA) Conference, Cape Town, South Africa, 19-23 September 2010.

(C) 2017 by the authors. Licensee MDPI, Basel, Switzerland. This article is an open access article distributed under the terms and conditions of the Creative Commons Attribution (CC BY) license (http://creativecommons.org/licenses/by/4.0/). 